\title{
Survey, Identification and Estimation of Damage in Major Diseases of Coconut
}

\author{
K. Athira* \\ Department of Plant Pathology, Tamil Nadu Agricultural University, \\ Coimbatore-641003, Tamil Nadu, India \\ *Corresponding author
}

A B S T R A C T

Coconut palm, despite its hardy nature, is affected by a number of diseases. A wide range of fungi attack different parts of coconut namely, crown, stem and root. Among the 173

Keywords

Coconut, Survey, Basal stem rot, Per cent Disease Index, Chowghat orange.

Article Info

Accepted:

07 October 2017

Available Online:

10 December 2017 fungal species reported on coconut, only a few cause serious disease problems and are difficult to control effectively. Root wilt disease, bud rot, basal stem rot, stem bleeding and leaf rot are the major diseases causing heavy crop losses in India. To estimate the major diseases of coconut in south farm, extensive field survey was undertaken from January to April 2017 followed by assessment of the damage level. The entire South farm was divided into 4 blocks. By following the methodology of Per cent Disease Index and Per cent Disease Incidence, the severity of these diseases that cause considerable yield loss and its incidence were recorded. The results revealed that compared to all other blocks, EF is found to be infected with 3 foliar diseases viz., Grey leaf blight, Leaf blight and Leaf rot with maximum disease incidence of $43.05 \%, 35.12 \%$ and $24.15 \%$ respectively. There was a notable increase of leaf blight in block $\mathrm{G}$ from $18.03 \%$ to $31.05 \%$ during the survey period. The diseases like Kerala wilt, Stem bleeding and Bud rot were observed at a minimum level. The variety Chowghat orange was susceptible to all foliar diseases observed in south farm.

\section{Introduction}

Coconut (Cocos nucifera Linn.) is an important plantation crop in India. It is cultivated for oil and raw materials used in the coir industry. The coconut palm globally cultivated in around 93 countries and in India, it is grown in 2.1 million ha $(2015-16$, 3rd estimates) with a production of 14,075 million nuts and an average productivity of 6,702 nuts/ha/year (CDB, 2016). Coconut farming and allied activities provide livelihood security to millions of people in India. The every part of a coconut tree has its own use or applications. It is generally called "Tree of Heaven", "Tree of Abundance", "Tree of
Life" and "kalpavriksha". Western literature mentioned the Malayalam name "Tenga" for the coconut palm which related to Tamil 'Tennai' and believed to have been introduced from Sri Lanka. The coconut is a benevolent crop and a perfect gift to mankind. It has during the span of history represented not only the source of food, beverage, oil seed, fibers, timber and health products but also associated with magic, mystery, medicine and omen in the life of people. The economic importance of this tree crop is evident from the fact that it is grown in more than 90 countries across the world in an area of 
14.231 million hectares producing about 57.514 billion nuts or 10.52 million tonnes of copra. However, Philippines, Indonesia, India and Sri Lanka account for 78 per cent of the area and production. India ranks third on world coconut map and in recent times became the largest producer of coconut with the production of 16.9 billion nuts from average under plantation of about 1.89 million hectares.

In the present scenario of climatic change this valuable plant is devastated by several fungal, bacterial, viral, viroid and phytoplasmal diseases that not only deteriorate the quality of fruits but also reduced the vigour and yield of palms. A wide range of fungi attack different parts of coconut namely, crown, stem and root. Among the 173 fungal species reported on coconut (Joseph and Radha, 1979), only a few cause serious disease problems and are difficult to control effectively. The major devastating diseases prevalent on coconut in Tamil Nadu are bud rot caused by Phytophthora palmivora, Tanjore Wilt (or) Basal stem end rot caused by Ganoderma lucidum, Kerala wilt caused by phytoplasma, Grey Leaf Spot caused by Pestalotiopsis palmarum, Stem bleeding disease caused by Thievolopsis paradoxa, Leaf blight caused by Lasiodiplodia theobromae. Due to seed borne, soil borne as well as air borne nature of these fungal diseases, the plants are infected from seedling to older stage and are suffering from immense losses in fruit yield of coconut. Hence, it is customary for the farmers to efficiently manage these setback diseases, for the farmers' income to attain.

Considering the above facts, the present study has therefore been under taken with the following objectives:

To identify the major diseases of Coconut Palm (Cocos nucifera L.) in south farm.
To find out the Per cent of disease incidence of major diseases of Coconut (Cocos nucifera L.) in south farm.

\section{Materials and Methods}

\section{Per cent disease index}

Survey was conducted in South Farm for assessing the per cent of disease incidence of Coconut from January to April 2017. The entire South farm was divided into 4 blocks (Figure 1). Twenty five trees were randomly selected from each block and percentage of disease incidence was recorded.

\section{Disease assessment}

The assessment of the amount of disease on a plant is essential in any quantitative epidemiological study. Disease assessment also forms the fundamental basis of many other aspects of Plant Pathology.

Assessment data are essential to breeders, fungicide manufacturers, economists, government agencies and academics in their various evaluations of resistance, treatment efficacy and resource priorities.

Most importantly, assessment of a particular disease in an individual crop over several years can provide indicators to elucidate the factors governing its incidence and severity. This information can also use to devise forecasting systems.

\section{Methods of assessment}

\section{Assessment in terms of percentage}

This method is applicable for those diseases which cause complete death of plants (e.g. Tanjore wilt, Kerala wilt, Bud rot, Stem bleeding). The per cent disease incidence is calculated using the following formula. 
Number of infected plants

Percent Disease Incidence = X 100

Total no. of plants observed

\section{Assessment using disease grades}

This method is useful to assess the foliar diseases like Grey Blight, Leaf Blight, Leaf Rot. The Plants are observed individually and severity percentage is arrived and the numerical rating is given as $0,1,2,3,4$ or 5 shown below. Normally, 50 or 100 plants or leaves are observed and individual rating is given. Per cent Disease Index (PDI) was worked out as per the standard grade chart (Ravinder Reddy, 1982).

The Per cent Disease Index was worked out as described by Mc Kinney's (1923).

PDI $=$ (Sum of numerical ratings $/$ Total number of leaves observed) $\times(100 /$ Maximum disease grade)

\section{Results and Discussion}

The present investigation was carried out to study the disease occurrence of coconut prevailing in south farm.

\section{Survey for the incidence of grey leaf blight/ leaf spot}

The incidence of grey leaf blight is noticed in south farm and the causal organism is Pestalotia palmarum. The most favorable condition for this pathogen is well drained soils or soils with potash deficiency, continuous rainy weather for 4-5 days and strong winds. Fixed plot survey was conducted for leaf blight disease and disease incidence of $42.07 \%$ was recorded in variety chowghat orange in EF block of south farm having 200 trees (Figure 2). This pathogen has previously been reported on coconut from Indian Andaman Islands (Rao, 1988), USA (Florida), Jamaica (Farr et al., 1989),
Australia, the Philippines and the Seychelles (Uchida and Aragaki, 1991).

\section{Survey for the incidence of leaf blight}

The incidence of leaf blight is noticed in south farm and the causal organism is Lasiodiplodia theobromae is an emerging serious problem in Pollachi tract. At present, the disease is spreading at a faster rate in Coimbatore, Erode, Dindigul, Tirunelveli, Kanyakumari and other districts of Tamil Nadu and causing 10 to 25 per cent yield loss. Fixed plot survey was conducted and $18.01 \%$ infection was reported in the variety DxT in D block and $35.18 \%$ in the varieties DxT and chowaghat orange in EF block. In G block the percent of infestation was $27.93 \%$ in variety DxT (Figure 3).

In Africa, anthracnose caused by Botryodiplodia palmarum, Melanconium sp. and Glomerella cingulata resulted in severe damage with important economic input, while in Southeast Asia Curvularia leaf blight (Curvularia eragrostidis) and Leptosphaeria leaf spot (Pestalotiopsis spp.) were common (Aderungboye, 1977).

\section{Survey for the incidence of leaf rot}

The incidence of leaf rot is noticed in south farm which is a complex disease caused by Colletotrichum gloeosporioides, Exserohilum rostratum and Fusarium spp. It is one of the important diseases in Tamil Nadu and Kerala. It was reported in 8 major southern districts of Kerala, besides Theni, Tirunelveli, Coimbatore and Kanyakumari districts of Tamil Nadu. Fixed plot survey was conducted and $23.16 \%$ infection was reported in EF block (Figure 4). Menon and Nair (1948) estimated the loss due to leaf rot as 5.6 million nuts annually. This is besides the loss in quality of the leaves rendering them unfit for thatching and other purposes. The loss due to leaf rot has been computed at 461 million 
nuts in Kerala as it is prevalent in 0.41 million ha (Nambiar and Rawther, 1993).

\section{Survey for the incidence of bud rot}

The incidence of bud rot is noticed in south farm and the causal organism is Phytophthora palmivora and more severe in young palms. The first indication of the disease is seen on the central shoot of the tree (spindle). It is widely distributed in Chengalpatu, Coimbatore, Cuddalore, Villupuram and Vellore Districts. $0.20 \%$ disease infection was recorded in $\mathrm{G}$ block by conducting roving survey for 2 year aged seedlings (Figure 5). The fungus remains as dormant mycelium in the infected tissues and also survives as chlamydospores and oospores in crop residues in the soil.

Fig.1 Map of south farm -division of various blocks

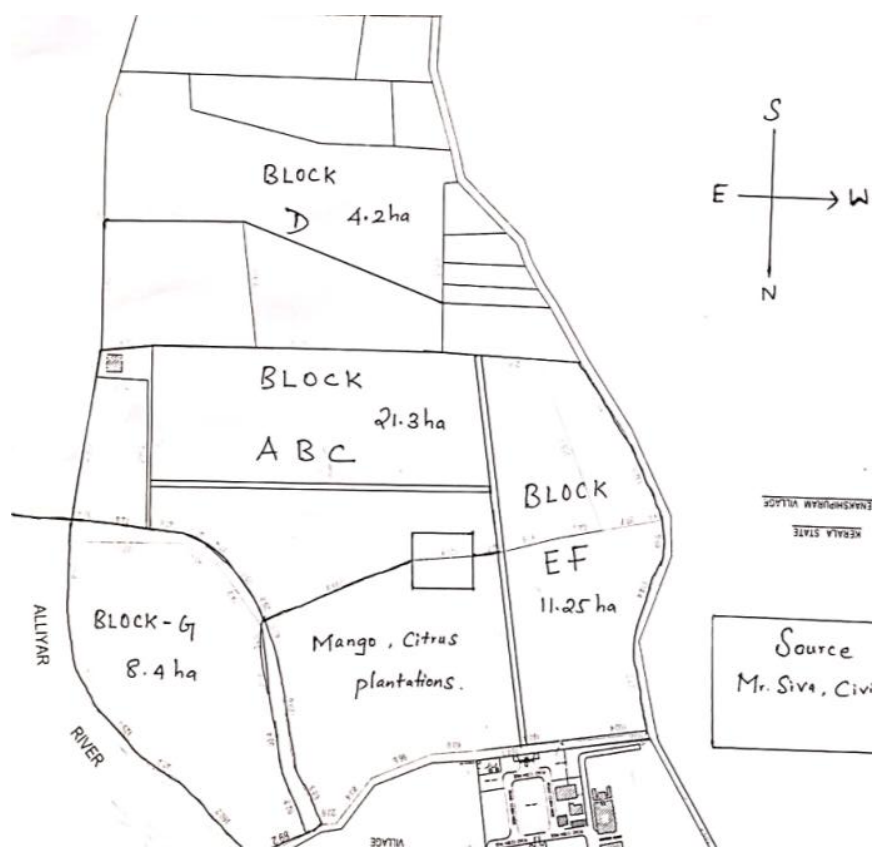

Fig.2 Symptoms of leaf spot/grey leaf blight in various stages
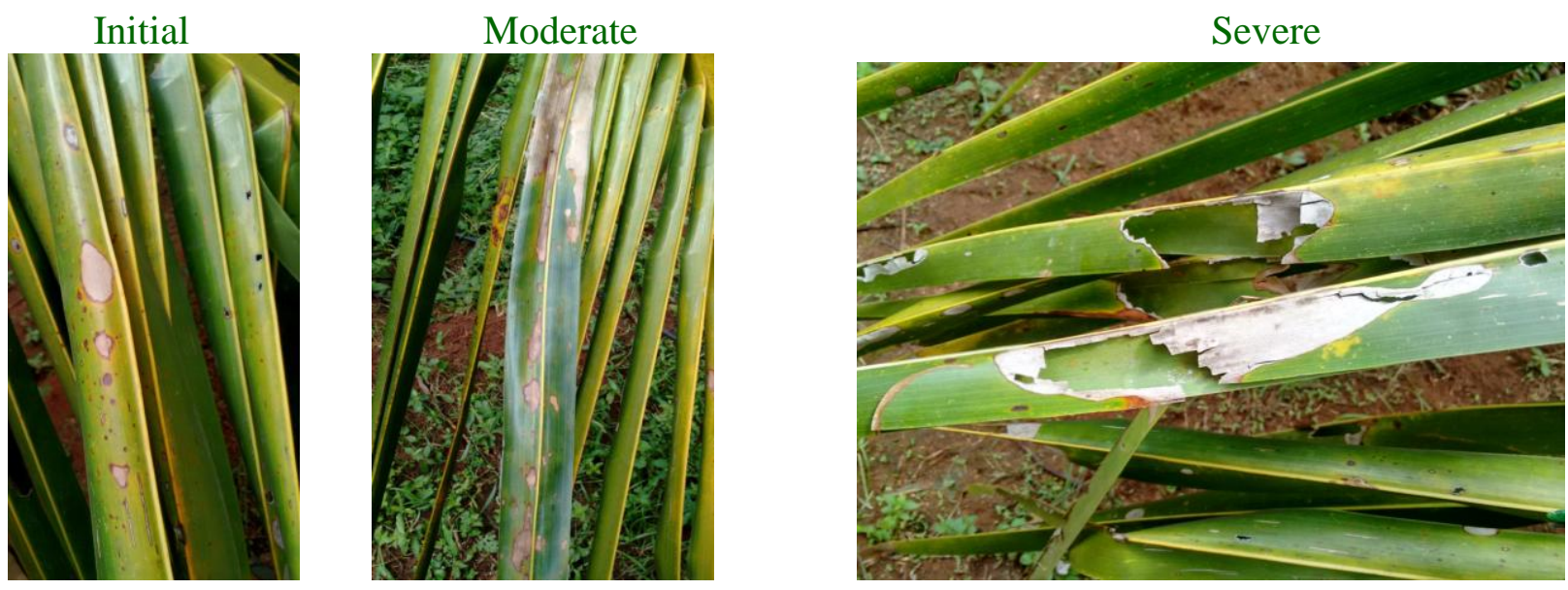
Int.J.Curr.Microbiol.App.Sci (2017) 6(12): 416-423

Fig.3 Symptoms of leaf blight in various stages
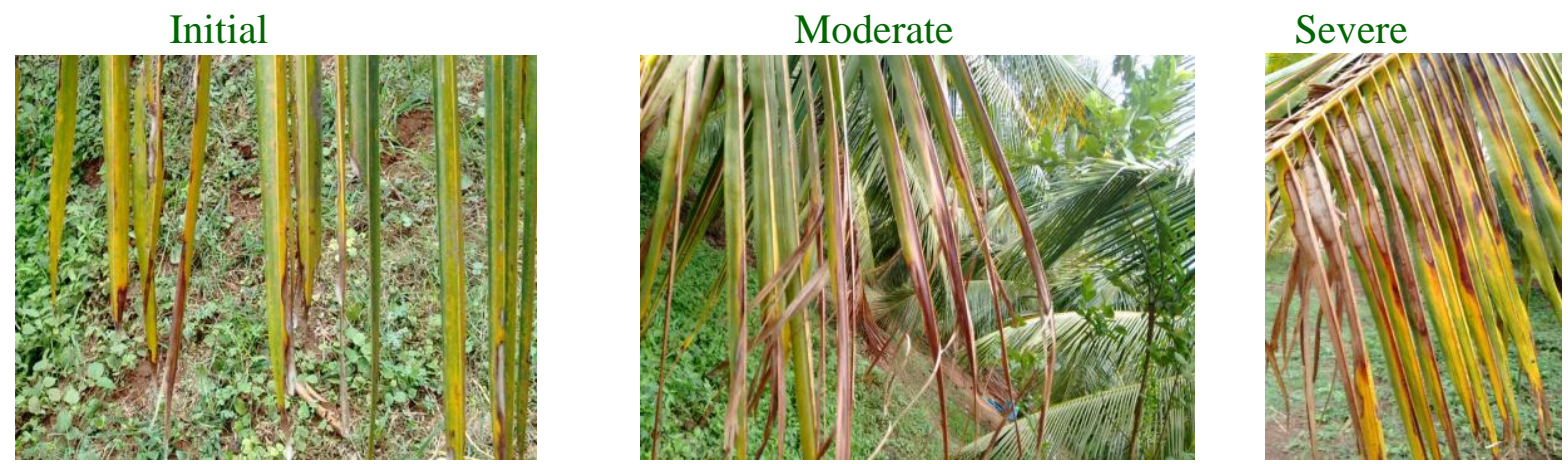

Fig.4 Symptoms of leaf rot in coconut

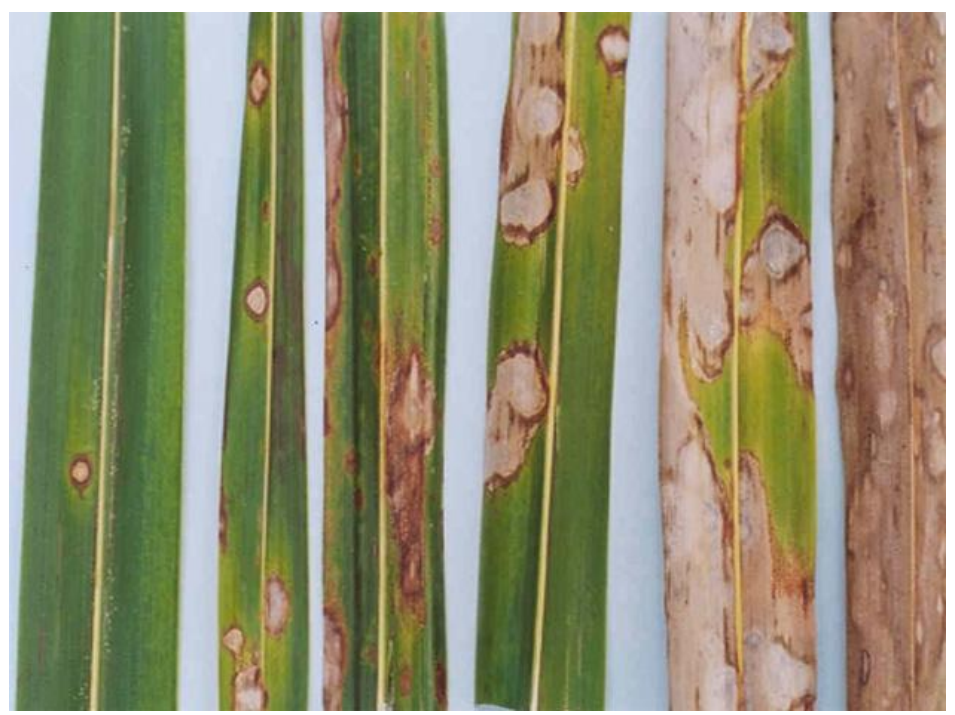

Fig.5 Symptoms of bud rot in various stages

Initial

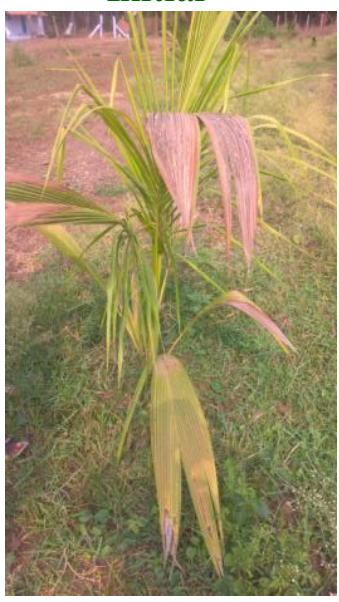

Severe

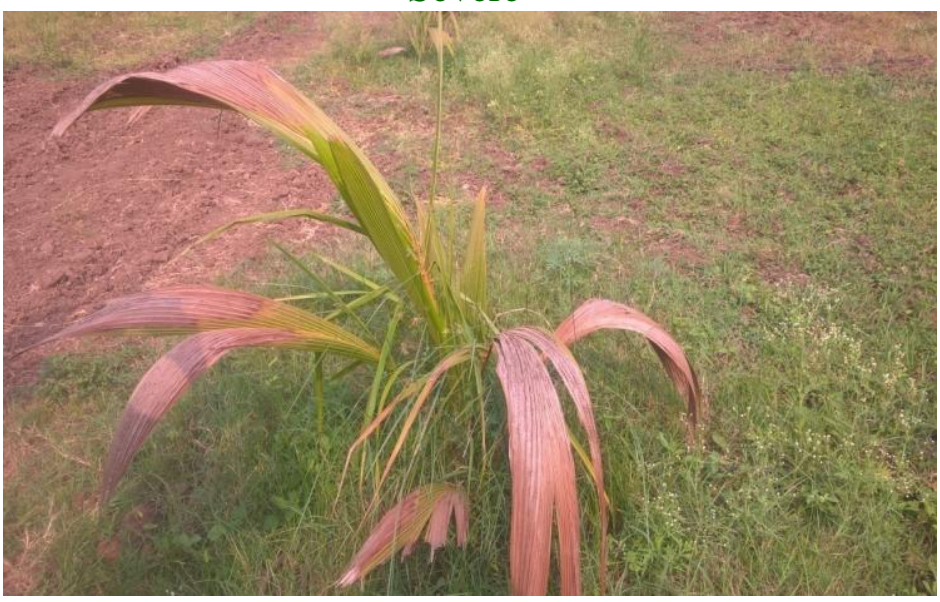


Fig.6 Symptoms of stem bleeding in various stages

Initial

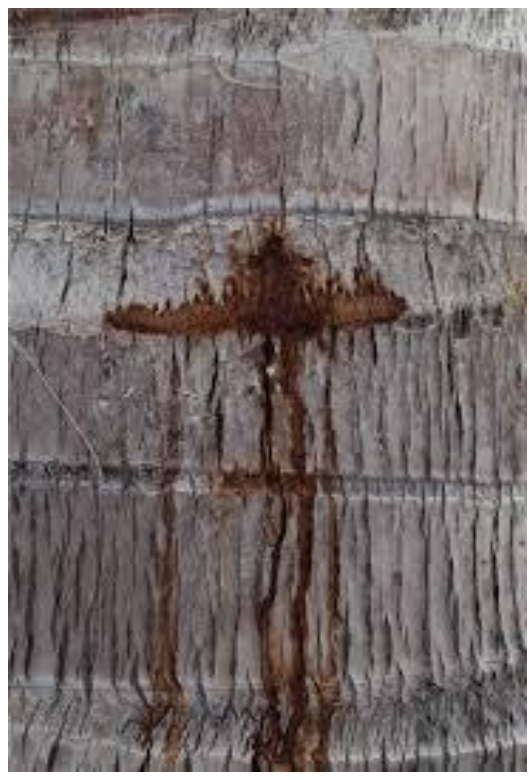

Severe

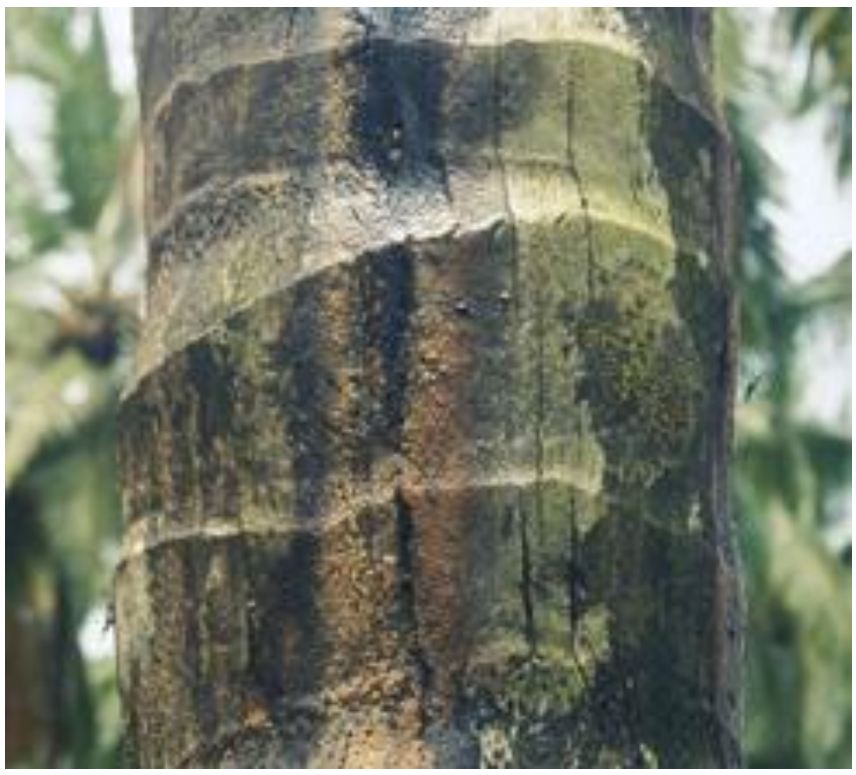

Fig.7 Symptoms of root wilt/Kerala wilt in various stages

Initial

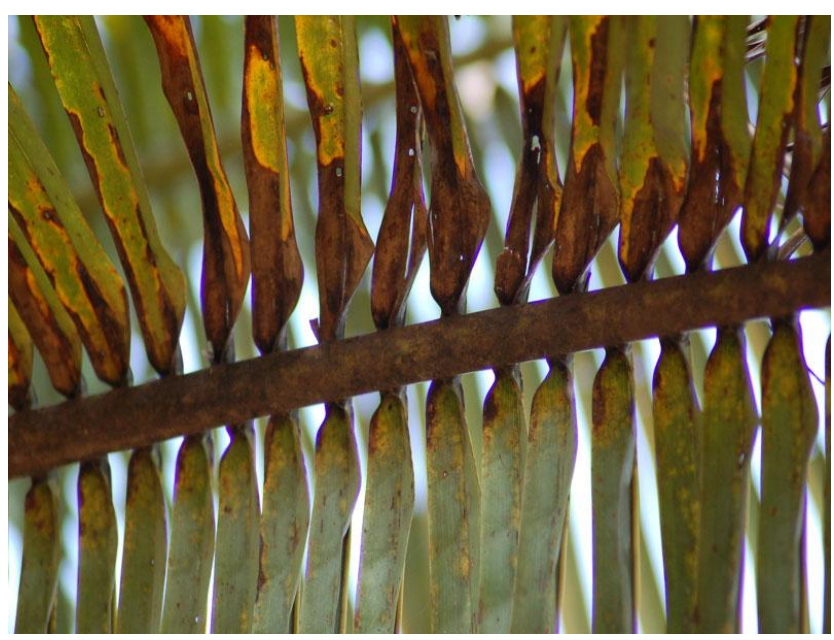

Severe

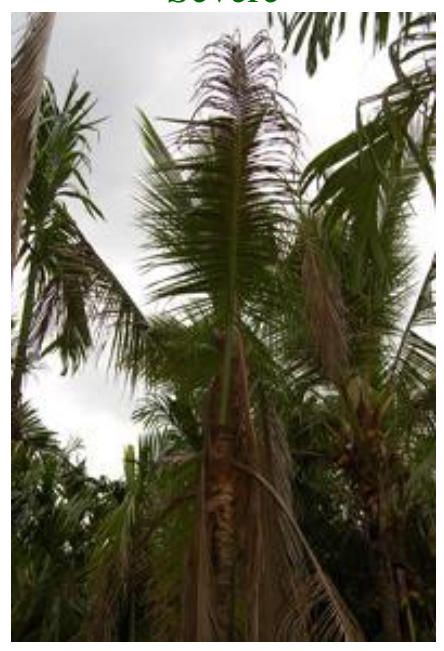

Disease score chart

\begin{tabular}{|c|c|}
\hline Grade & Description (\% leaf area infected) \\
\hline 0 & No sign or symptoms \\
1 & $0-10 \%$ infection \\
3 & $11-15 \%$ infection \\
5 & $16-25 \%$ infection \\
7 & $26-50 \%$ infection \\
9 & $>50 \%$ infection \\
\hline
\end{tabular}


Some of the research findings also support this study. An incidence of 0.1 to 6.5 per cent in Kerala and 0.4 to 6.7 per cent in Tamil Nadu has been reported (Radha and Joseph, 1974). The disease is also prevalent in East and West coasts of India (Menon and Pandalai, 1958). The problem has been reviewed earlier (Nambiar and Rawther, 1993). Rainfall appears to be an important factor and heavy disease incidence that prevailed during October 1992 was attributed to high rain fall when about 5000 palms of 25-30 years age group were affected in Kuttiadi area of Calicut district of Kerala.

Serious outbreaks of Phytophthora bud rot of coconut were recorded in the Philippines, in Laguna province, between 1961 and 1967 when 25,000 coconut palms became infected (Celino, 1970).

\section{Survey for the incidence of stem bleeding}

It is one of the most important diseases of coconut and mostly found in Thanjavur and Kanyakumari districts. The causal organism for the disease is Ceratocystis paradoxa. About $0.10 \%$ infestation was reported in block $\mathrm{ABC}$ and $0.11 \%$ infestation in block EF respectively (Figure 6). Some of the research findings supported this study. 50\% losses were recorded in some plots of Malayan Green Dwarf plantations due to stem bleeding in Sergipe over the 2004-2007 period. Palm death occurred between 4 months and a year after the first symptoms (Dollet Michel et al., 2012).

\section{Survey for the incidence of Kerala wilt}

Kerala wilt is a phytoplasmal disease and it is transmitted by vector namely Proutista moesta. In Tamil Nadu, it occurs in Coimbatore, Tirunelveli and Kanyakumari districts. Infestation of $0.05 \%$ was reported on $\mathrm{AB}$ block in West coast tall variety.
The disease intensity of Kerala wilt in the contiguous disease tract ranged from 1.5 per cent in Thiruvananthapuram district to 75.6 per cent in Kottayam district. The annual loss due to disease is estimated to be about 968 million nuts. The recent survey conducted by Department of Agriculture, Kerala showed that the disease incidence has been reduced by 24.0 per cent. The reasons for decline in the disease incidence is attributed to removal of diseased palms, replanting with quality seedlings, replacement of coconut with rubber and adoption of integrated disease management practices developed by CPCRI (Jacob Mathew et al., 1998). In Coimbatore district, disease incidence was noticed in Manakkadavu village of Anaimalai block. Out of 2000 palms surveyed, 65 palms were found to be infected in Manakkadavu village (Figure 7). Mathew et al., (1993) reported a decline in yield to the tune of 45 per cent in West Coast Tall variety and $60 \%$ in DxT hybrids and delayed bearing of seedlings that took up the infection.

\section{References}

Aderungboye, F.O. 1977. Disease of the oil palm. Trop. Pest Manage. 23: 305-326.

CDB. 2016. Coconut Statistics 2015-16. Coconut Development Board, India http://www.coconutboard.gov.in/present ation/ statistics.

Celino, M. S.1970. Bud Rot Control. In: Coconut production. Ed. by R.G. Emata (Philippines) p. 72-75.

Dollet, M., De Franqueville, H., Ducamp, M. 2012. Bud rot and other major diseases of coconut, a potential threat to oil palm. Existing and Emerging Pests and Diseases of Oil Palm - Advances in Research and Management $=4$ th IOPRI-MPOB International Seminar, 13-14 December 2012, Bandung, Indonesia

Farr, D. F., Bills, G. F., Chamuris, G. P., 
Rossman, A. Y. 1989. Fungi on Plants and Plant Products in the United States. St. Paul, Minnesota, USA, APS Press.

Jacob Mathew., Rawther, T. S. S., Pillai, N. G. 1998. Origin, distribution and production loss In: Coconut Root (Wilt) Disease, Central Plantation Crops Research Institute, Kasragod.1-7p.

Joseph, T., Radha, K. 1979. Coconut disease and quarantine regulations. Technical document No: 7/8 of the Plant Protection Committee for the South East Asia and Pacific Region -FAO 14 p.

Mathew, J., Cecil, S. R., Amma, P. G. K., Pillai, N. G. 1993. Impact of root (wilt) disease on the yield of young coconut palms. In: Advances in coconut research and development, Oxford and IBH Publishing Co. Pvt. Ltd., pp. 605-615.

Mckinney, H. H. 1923. A new system of grading of plant diseases. J. Agric. Res. 26:195-218.

Menon, K. P. A., Pandalai, K. M. 1958. The coconut palm, A monograph. Indian Central Coconut Committee, Emakulum. 384 p.

Menon, K. P. V., Nair, U. K. 1948. The leaf rot diseases of the coconut in Travancore and Cochin. Indian Coconut J. 11: 33-39.

Nambiar, K. K. N., Rawther, T. S. S.1993. Fungal diseases of coconut in the world. In: Advances in Coconut Research and Development, Oxford and IBH PubI.Co.Pvt.Ltd.,New Delhi. 546-561p.

Radha, K., Joseph, T. 1974. Investigations on the bud rot disease (Phytophthora palmivora Bud.) of coconut. Final report, PL 480 scheme. 32p.

Rao, S. C. 1988. Leaf Spot disease of coconut incited by Bipolaris incurvata (Bernad) Alcorn. Current Science 57: 674-675.

Uchida, J. Y., Aragaki, M. 1991. Bipolaris and Exserohilum leaf spots. In: Chase AR, Broschat TK, eds. Diseases and Disorders of Ornamental Palms. St Paul, MN, USA: APS Press, 55.

\section{How to cite this article:}

Athira, K. 2017. Survey, Identification and Estimation of Damage in major Diseases of Coconut. Int.J.Curr.Microbiol.App.Sci. 6(12): 416-423.

doi: https://doi.org/10.20546/ijcmas.2017.612.050 